\title{
New Records of Katydids of the Genus Quiva (Orthoptera: Tettigoniidae: Phaneropterinae) to Brazil
}

\author{
Rafael Segtowick da Silva Sovano ${ }^{\bowtie}$ \& Diego Matheus de Mello Mendes
}

Instituto Nacional de Pesquisas da Amazônia, e-mail: rafaelsovano@hotmail.com (Autor para correspondência ${ }^{\varpi}$ ), diego.mello.mendes@gmail.com.

\section{EntomoBrasilis 6 (3): 251-254 (2013)} Abstract. This paper reports a new record of Quiva diaphana Hebard and Quiva pulchella Rehn to Brazil along with the occurrence of Quiva abacata
(Brunner von Wattenwyl) for the first time in the Brazilian Amazon, including distribution notes.

Keywords: Amazon; Collections; Distribution; Ensifera.

\section{Novos Registros de Esperanças do Gênero Quiva (Orthoptera: Tettigoniidae: Phaneropterinae) para o Brasil}

Resumo. Este trabalho reporta novos registros de ocorrência de Quiva diaphana Hebard e Quiva pulchella Renh para o Brasil, juntamente com a ocorrência de Quiva abacata (Brunner von Wattenwyl) pela primeira vez para a Amazônia brasileira, incluindo notas de distribuição.

Palavras-chave: Amazônia; Coleções; Distribuição; Ensifera.

$(5$ rasshoppers, crickets and katydids (order Orthoptera) are recognized not only for their economic importance as potential agricultural pests, but also for their ecological role, being indispensable elements at different levels in food chains as the main prey of many vertebrates and other invertebrates including other insects (NunEs-GuTJAHR \& BRAGA 2010). Moreover, they contribute directly to the cycling of plant matter as natural defoliators (NunEs-GUTJAHR \& BrAGA 2010). Among the 33 families belonging to the order Orthoptera, there is the family Tettigoniidae whose representatives are commonly known in Brazil as "esperanças" (Hogue 1993; RENTZ 2010).

Tettigoniidae possesses 19 subfamilies distributed worldwide, five of which occur in Brazil and in the Brazilian Amazon: Conocephalinae, Listroscelidinae, Meconematinae, Pseudophyllinae and Phaneropterinae. Currently the largest of the subfamilies of Tettigoniidae, Phaneropterinae possesses more than 2.300 described species (RENTZ 2010; SPERBER et al. 2012; EADES et al. 2013). In Brazil this subfamily includes 283 species distributed into 83 genera (SPERBER et al. 2012; EADEs et al. 2013) divided into 14 tribes, among which is the tribe Dysoniini, whose representatives are characterized by a chromatic body color resembling tree bark or rock surfaces covered by lichens and bryophytes (Hogue 1993; CADENA-CASTAÑEDA 2011). Dysoniini is a strictly neotropical tribe composed up to date by 13 genera including the genus Quiva (EADEs et al. 2013).

The representatives of the genus Quiva are easily recognized by their remarkable white-yellow color pattern covered with black punctures. They also have antennae with densely hairy black rings on the dorsal surface at least in its middle portion, when they are extended (REHN 1950).

During visits to Brazilian entomological collections, 35 specimens of Quiva were found, 14 of those from the Invertebrate Collection of the National Institute of Amazonian Research (INPA), one from the Collection of Invertebrates of the Museum Paraense Emílio Goeldi (MPEG), 11 from the Zoological Collection of the University of the Maranhão State and nine from the Zoological Collection of Federal University of Amazonas. These specimens were identified following the key of species proposed by REHN (1950).

The description of Quiva abacata (Brunner von Wattenwyl) (Figure 1a) reports the posterior margin of the lateral lobes of pronotum broadly arched with the ventral margin, sub-genital plate without lobes and widely produced (Figure $1 \mathrm{~b}$ ); cerci provided with a short denticle on its dorsodistal part (BRUNNER VON WATtENWYL 1878; REHN 1950). This species was recorded for Maroni in French Guiana, Moengo in Suriname and in Itauna Valley, Espírito Santo state, southeastern Brazil (ReHN 1950; EADES et al. 2013). That being so this species is registered for the first time in the Brazilian amazon rainforest in the states of Amazonas, Pará and Maranhão.

Examined material: $18 \hat{\mathrm{e}} 19$ - BRASIL, Amazonas, Manaus, ZF2, km 14 - torre 40m, 21-24.i.2004, (C.S. Motta, S. Trovisco, A. Silva Filho \& F.F. Xavier Filho) $\left[02^{\circ} 35^{\prime} 21\right.$ ”S - 60 ${ }^{\circ} 06$ ' $\left.55^{\prime \prime W}\right]$ (1ठ); idem, 16-19.viii.2004, (J.A. Rafael, C.S. Motta, A. Silva Filho, S. Trovisco \& J.M.F. Ribeiro)[02 $\left.{ }^{\circ} 35^{\prime} 21^{\prime \prime S}-60^{\circ} 06^{\prime} 55^{\prime \prime W}\right]$ (1 $\left.\mathrm{O}^{\top}\right)$; idem, 15-18.vi.2004, (J.A. Rafael, C.S. Motta, F. Godoi, S. Trovisco \& A. Silva Filho) $\left[02^{\circ} 35^{\prime} 21^{\prime \prime} S-60^{\circ} 06^{\prime} 55^{\prime \prime W}\right]\left(2{ }^{\wedge}\right)$; idem, Base LBA, 10-11.vii.2008 (J.A. Rafael \& F.F. Xavier Filho) [02 $\left.{ }^{\circ} 35^{\prime} 37^{\prime \prime} \mathrm{N}-60^{\circ} 1239 \mathrm{~W}\right]\left(1 \mathrm{O}^{\top}\right)$; idem, 04.iii.2011, 03:00-06:0oh, (J.A. Rafael e equipe)[02 $\left.35^{\circ} 21^{\prime \prime S}-60^{\circ} 06^{\prime} 55^{\prime \prime W}\right]\left(10^{\top}\right)$, mobile light trap; idem, Itacoatiara, CEPLAC - km 30, 28.iii.1977,

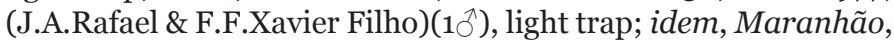
Bom Jardim, REBIO - Base Reserva Biológica Gurupi, 05 15.vi.2010, (J.C. Silva, J. A. Silva, A.A. Santos \& T.T.A)(2犬̂ e 1), light trap; idem, 02-11.ix.2010, (F. Limeira-de-Oliveira, 
T A.L. Costa, J.A. Silva \& M.M. Abreu) $\left(4{ }^{\Uparrow}\right)$; Cidade Nova do Maranhão, REBIO - Reserva Biológica Gurupi, light trap, 01o6.iii.2011, (F. Limeira-de-Oliveira, M.M. Abreu \& J.A. Silva)

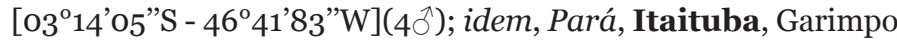
Tocantinzinho, 04-18.x.2010, (B. Mascarenhas \& J. Dias)

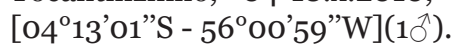

Quiva diaphana Hebard (Figure 2a) is characterized by not having the knotted process between the apex of the vertex and the fastigious of the forehead as in Q. abacata; cerci slightly elongated, robust and twith cultriform margins, sub-genital plate enlarged, with two lobes in its distal portion (Figure 2b) (HEBARD 1927; ReHN 1950). This species was previously recorded only to the department of Cundinamarca in central Colombia (REHN 1950) and now is recorded for the first time in Brazil, Amazonas state.

Examined material: $5 \hat{c}$ - BRASIL, Amazonas, Manaus, ZF2, km 14 - torre 40m, 21-24.i.2004, (C.S. Motta, S. Trovisco, A. Silva Filho \& F.F. Xavier Filho) $\left[02^{\circ} 35^{\prime 21}\right.$ ”S - 60º6' $\left.55^{\prime \prime} \mathrm{W}\right]$
(1今), mixed light bedsheet trap; idem, 16-19.viii.2004, (J.A. Rafael, C.S. Motta, A. Silva Filho, S. Trovisco \& J.M.F. Ribeiro) [02 ${ }^{\circ} 35^{\prime} 21^{\prime \prime} \mathrm{S}$ - 60 $\left.{ }^{\circ} 06^{\prime} 55^{\prime \prime} \mathrm{W}\right]\left(1{ }^{\top}\right)$; idem, 13-16.ix.2004, (A.R. Ururahy, F.F. Xavier Filho, F. Godoi \& S. Trovisco)[02 $2{ }^{\circ} 35^{\prime 21}$ ”S

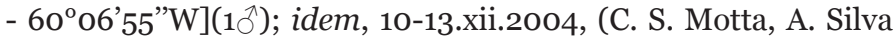
Filho, S. F. Trovisco \& M. Cutrim) [02 $\left.{ }^{\circ} 35^{\prime 2} 21^{\prime \prime} \mathrm{S}-60^{\circ} \mathrm{O} 6{ }^{\prime} 55^{\prime \prime W}\right]$

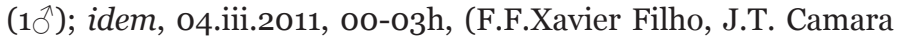
\& P.Dias $)(1 \overbrace{}^{\Uparrow})$.

Quiva pulchella Rehn (Figure 3a) can be distinguished from other species by having elongated, slender and tweezer shaped cerci with its dorsal margin straight in lateral view and its ventral margin subparallel; cerci apex enlarged with its distal margin oblique and sub-truncate having a distinct dorsal spine (Figure 3b) (ReHn 1950). This species was previously knowned only to Peru in Sierra Leonpampa and Avispa by the margins of the Madre de Dios river (EADES et al. 2013; REHN 1950), now being registered for the first time for Brazil in different localities of the Amazonas state.
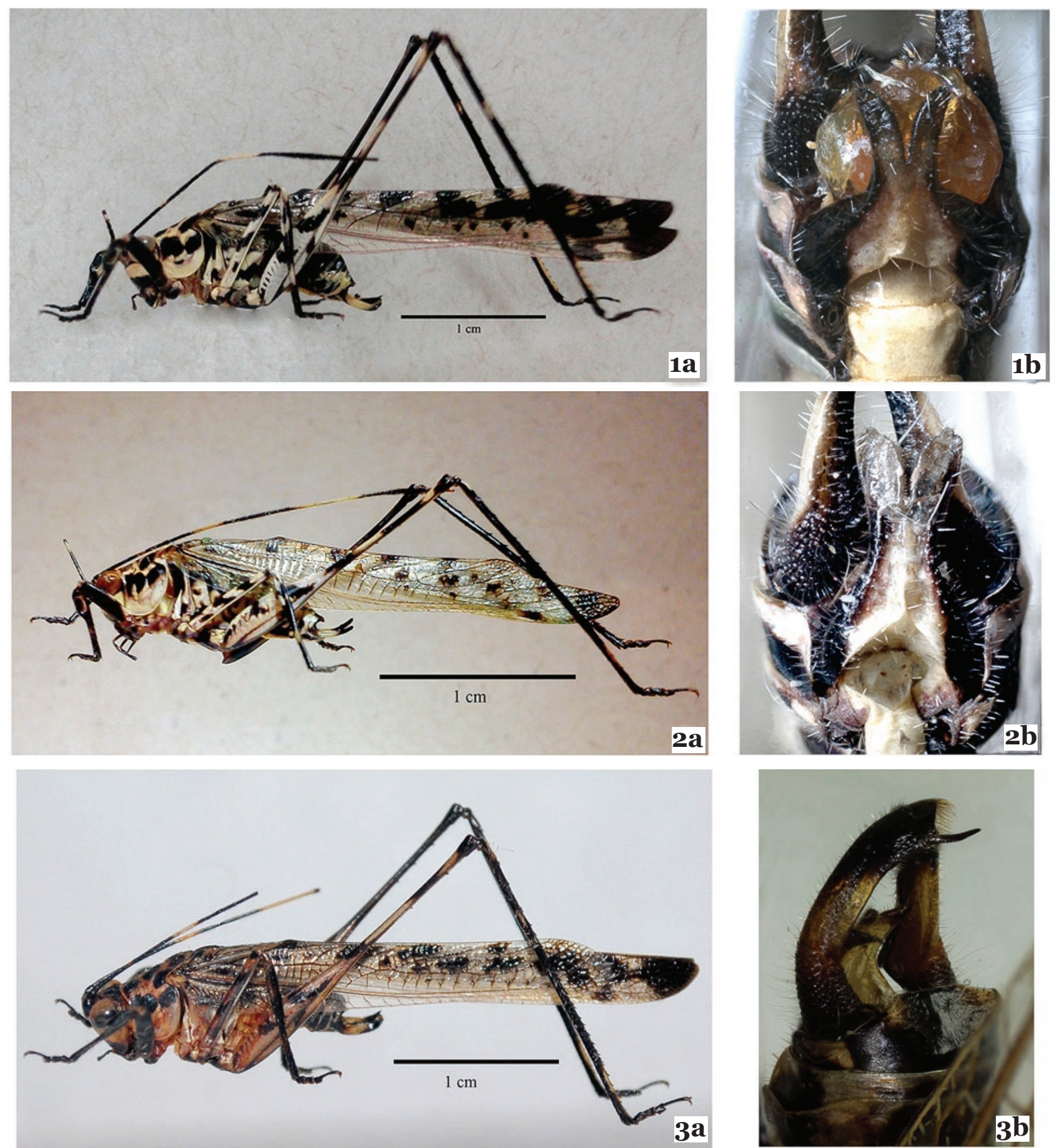

Figure 1-3. Lateral view of Quiva abacata (1a); ventral view of the subgenital plate of Q. abacata (1b); lateral view of Quiva diaphana (2a), ventral view of the subgenital plate of $Q$. diaphana (2b); lateral view of the Quiva pulchella (3a); dorso-lateral view of the male cerci of $Q$. pulchella. 
Examined material: $11 \hat{\jmath}$ - BRASIL, Amazonas, Autazes, LIT-1 AM, 21-22.vii.1996, Black light BLB, (P.F.Bührnheim \& N.O. Aguiar) $\left[03^{\circ} 32^{\prime} 5.7^{\prime \prime S}-59^{\circ} 13^{\prime} 30^{\prime \prime} \mathrm{W}\right]\left(1{ }^{\wedge}\right)$; idem, Coari, Rio Urucu, Igarapé Marta-3, 14-25.viii.1993, (P.F. Bührnheim et al.) $\left[04^{\circ} 50^{\prime} 0.73^{\prime \prime S ~}-65^{\circ} \mathrm{O} 2^{\prime} 37^{\prime \prime} \mathrm{W}\right]\left(2{ }^{\top}\right)$, mixed mercury light; idem, 07-16.ix.1994, (P.F.Bührnheim et al.)[0443'24”S - 65 40’06”W](1 $\left.0^{\top}\right)$, mixed mercury light; idem, Rio Urucu, LOC - 18, 19.ii-01.iii.1993, (P.F. Bührnheim \& N.O. Aguiar) [04 53 '53"S - 65 $\left.{ }^{\circ} 11^{\prime} 58^{\prime \prime} \mathrm{W}\right]\left(1 \mathrm{O}^{\top}\right)$, mixed mercury light; idem, Juruá, Mineruazinho, 13-25.i.1996, (P.F. Bührnheim, N.O. Aguiar et al.)[03 $\left.34^{\prime} 85^{\prime \prime S}-66^{\circ} 59^{\prime} 15^{\prime \prime} \mathrm{W}\right]\left(1{ }^{\wedge}\right)$, mixed mercury light; idem, Novo Airão, Ramal do Olímpio, 03-15.vii.1997, (P.F. Bührnheim, N.F. Fe \& N.O. Aguiar) [02 39 '23”S - 60 $\left.55^{\circ} 44^{\prime \prime} \mathrm{W}\right]$ $\left(3{ }^{\top}\right)$, mixed mercury light; idem, Nova Olinda do Norte, Rio Abacaxis, 35m, 27-29.v.2008, (J.A. Rafael and team)[05 ${ }^{\circ} 15$ '09”S $\left.-58^{\circ} 41^{\prime} 52^{\prime \prime} \mathrm{W}\right]\left(1{ }^{\Uparrow}\right)$, light trap on the boat; idem, Uarini, 22.vii-

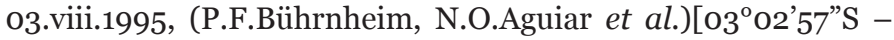
$\left.65^{\circ} 41^{\prime} 42^{\prime \prime W}\right]\left(1{ }^{\top}\right)$, pennsylvania black light trap, BLB.

The new distribution records (Figure 4) presented here along with biology and diversity data about katydids suggest that many Phaneropterinae species have yet to be found. In addition many localities in the Brazilian amazon rainforest remain virtually unexplored, such as the border regions with Peru, Colombia and Acre state as well as the southeast of Pará state being necessary the realization of sampling so as to discover the real diversity of these orthopterous for this region. Therefore, further studies on the Brazilian amazon rainforest certainly will extend the knowledge concerning of the Phaneropterinae fauna.

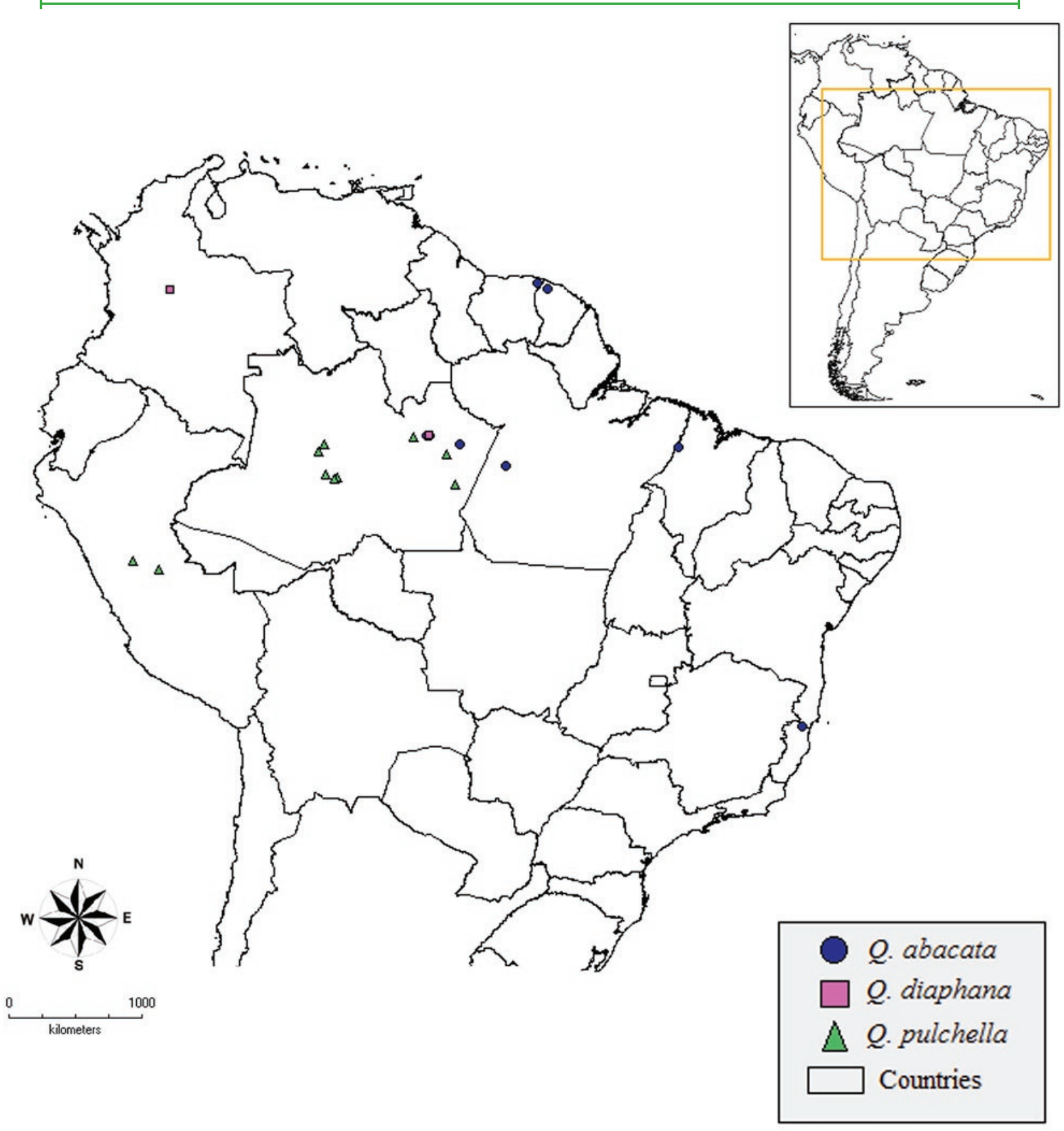

Figure 4. Geographical distribution of the genus Quiva.

\section{ACKNOWLEDGEMENTS}

We thank to Jeane Marcelle C. do Nascimento (INPA) by the treatment performed in the images of this work and Marlon Breno Costa Santos da Graça (INPA) for reviewing the text. We thank the Laboratory of Aquatic Insects and Cytotaxonomy and Diptera Systematics Laboratory for providing the equipment to obtain the images and all the curators and collections visited for the assistance.

\section{REFERENCES}

Brunner von Wattenwyl, C., 1878. Monographie der Phaneropteriden. Herausgegeben von der K. K. ZoologischBotanischen Gesellschaft in Wien, 146-148

Cadena-Castañeda, O.J., 2011. La Tribu Dysoniini Parte I: El Complejo Dysonia (Orthoptera: Tettigoniidae) Y Su Nueva Organización Taxonómica. Journal of Orthoptera Research, 20: 51-6o. 
Tades, D.C., D. Otte, M.M. Cigliano \& H. Braun, 2013 Orthoptera Species File. Versão 5.0/5.0. Disponível em: <http://orthoptera.speciesfile.org > [Acess: April/ 03/2013].

Hebard, M., 1927. Studies in the Dermaptera and Orthoptera of Colombia. Transactions of the American Entomological Society, 52: 276.

Hogue, C.L., 1993. Latin American Insects and Entomology. Los Angeles, University of California Press, 536p.

Nunes-Gutjahr, A.L. \& C.E.S. Braga, 2010. Similaridade entre amostras da Acridofauna (Orthoptera: Acrididae) em quatro áreas ao longo da estrada Santarém-Cuiabá (Br-163), Pará, Brasil. Revista Nordestina de Zoologia, 4: 118-130.

Rehn, J.A.G., 1950. Studies in the Group Dysoniae (Aphidniae of authors) (Orthoptera: Tettigoniidae: Phaneropterinae) (Part I). Transactions of the American Entomological Society, 75: 271-322.
Rentz, D., 2010. A Guide to the Katydids of Australia. CSIRO Publishing, Austrália, 214p.

Sperber, C.F., C.M. Mews, M.G. Lhano, J. Chamorro \& A. Mesa, 2012. Orthoptera, p. 271-287. In: Rafael, J.A., G.A.R. Melo, C.J.B. Carvalho, S.A. Casari \& R. Constantino (Eds.) Insetos do Brasil Diversidade e Taxonomia. Holos Editora. Ribeirão Preto, São Paulo, 796p.

\section{Recebido em: o7/o6/2013}

Aceito em: 29/o9/2013

\section{Como citar este artigo:}

Sovano, R.S.S. \& D.M.M. Mendes, 2013. New Records of Katydids of the Genus Quiva (Orthoptera: Tettigoniidae: Phaneropterinae) to Brazil. EntomoBrasilis, 6(3): 251-254.

Acessível em: http://www.periodico.ebras.bio.br/ojs/index.php/ebras/article/view/362. doi:10.12741/ebrasilis.v6i3.362

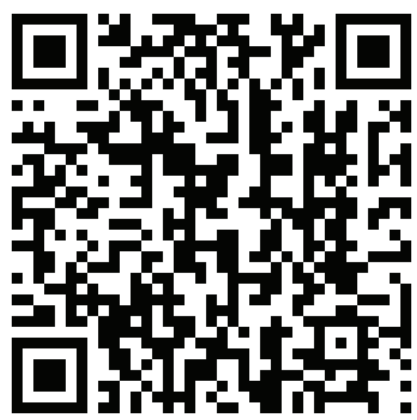

